橋渡し研究

一最近の変化と現状の問題点一

中川 敦寛 ${ }^{122)}$, 佐藤 千穂 ${ }^{1)}$, 八木橋 真央 ${ }^{1)}$, 高橋 千明 ${ }^{1)}$, 冨永 悌二 ${ }^{2)}$

1）東北大学病院臨床研究推進センターバイオデザイン部門, 2) 同 大学院医学系研究科神経外科学分野

\title{
Translational Research : Current Update and Problems
}

\author{
Atsuhiro Nakagawa, M.D., Ph.D. ${ }^{\left.1{ }^{2}\right)}$, Chiho Sato ${ }^{1)}$, Mao Yagihashi, M.D. ${ }^{1)}$, Chiaki Takahashi ${ }^{1)}$, and Teiji \\ Tominaga, M.D. ${ }^{2)}$
}

1) Department of Biodesign, Clinical Research, Innovation and Education Center, Tohoku University Hospital, 2) Department of Neurosurgery, Tohoku University Graduate School of Medicine

We have been organizing the Academic Science Unit infrastructure that enables medical and healthcare developers to identify bedside needs that have commercial potential. Since its inception in 2014, we have accepted over 1,200 corporate researchers in Tohoku University Hospital to identify medical needs with the support of medical professionals. We are trying to develop ways to create new value for the patients and medical professionals by educating more medical professionals to become liaisons in other fields, including business and technology. We are also trying to accommodate emerging technology, such as augmented reality to medical environment, and are changing our workstyle.

(Received October 10, 2019; accepted November 27, 2019)

Key words : alliance, biodesign, emerging technology, open innovation, translational research

Jpn J Neurosurg（Tokyo）29: 760-767, 2020

\section{はじめに}

橋渡し研究とは英語では translational research (TR) と 呼ばれる研究分野に対応するものであり,「先端医科学 研究の臨床への応用の推進に関する懇談会検討報告書」 〔平成 18（1996）年 6 月 28 日科学技術 ·学術審議会研究 計画・評価分科会ライフサイエンス委員会決定】では, 「大学等において, アカデミア（研究者・医師）が主導 し, 基礎研究の成果について, シーズの発掘からヒトへ の応用を目指した前臨床研究, ヒトを対象に行う臨床研 究（非臨床試験を含む）の一部など, 最終的には実際の 医療に用いることを目指し，製薬企業等が研究開発に参
画するなど，実用化の見通しが立つまでの橋渡し研究」 （懇談会報告書の記載をそのまま引用）と定義してい $ろ^{3)}$. また, 米国国立衛生研究所 (National Institute of Health：NIH）で橋渡し研究を所管する National Center for Advancing Translational Sciences (NCATS) のウェブサ イトにおいては “Translation is the process of turning observations in the laboratory, clinic and community into interventions that improve the health of individuals and the public - from diagnostics and therapeutics to medical procedures and behavioral changes” と定義されている ${ }^{8)}$.

最近の科学・技術の進展は目覚ましいものがあり, 生 体や疾患の機序を含めて遺伝子レベルを含むさまざまな

連絡先：中川敦寛， $=981-8574$ 仙台市青葉区星稜町 1-1 東北大学病院臨床研究推進センターバイオデザイン部門

Address reprint requests to: Atsuhiro Nakagawa, MD., Ph.D., Department of Biodesign, Clinical Research, Innovation and Education Center, Tohoku University Hospital, 1-1 Seiryo-machi, Aoba-ku, Sendai-shi, Miyagi 980-8574, Japan 
解析がなされ, その結果, 医療手段の領域は大きく広 がった. さらに, 成功確率の低下, 研究開発費の高騰も 相まって, 1 企業の研究所のみではすべてを網羅するこ とが困難となってきている。こうした問題を解決するた めに米国をはじめ, 世界各国でさまざまな取り組みがさ れてきた。現在，世界的な動向としては，創薬・医療機 器企業は自社による基礎研究を自社の得意分野に絞り, ベンチャー企業やアカデミアのシーズを導入して開発を 行う, オープンイノベーションの方向に舵を切り, でき るかぎり研究開発費などの資源を開発後期の臨床試験に 集中投資させるのが潮流となっている。このため新規医 療技術の創出に関してはアカデミアが有する役割は非常 に大きなものとなっており, 事実, 最近臨床の現場に提 供される革新的な医療手段はアカデミアを起源とするも

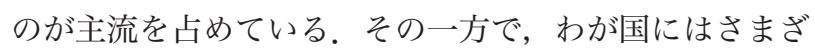
まな新規医療技術のシーズは十分存在しているものの, それを育成して, 実用化に結び付け, 産業としての成果 に導くことについては十分に発揮できていない状況と なっていた。わが国が有する高い潜在的能力を生かし て, 創薬・医療機器を含めた医療産業の活性化に結び付 ける具体的な方策を産官学一丸となって講じることが求 められるようになった。

こうした流れを受け，わが国では，文部科学省によつ て実施された（2007度より「橋渡し研究支援推進プログ ラム」. 事業期間：2007 2011 年度末) が開始され, 2012 年度より「橋渡し研究加速ネットワークプログラム」(事 業期間：2012２016 年度末．2017年度より AMED に業 務移管）を経て,「橋渡し研究戦略的推進プログラム」〔事 業期間：2017〜2021 年度末 (予定)]が実施され，この 事業を中心として TR を推進する政策, 事業が実施され ている.

わが国ではバイオベンチャーを介したエコサイクルの 構築がまだ途上であると理解されているが, TRを推進 するための一連の政策や事業の成果により, 大学を起源 とする研究成果を企業へと導出するという事例も認めら れつつあり, オープンイノベーションの環境についても 徐々に構築されてきている。ただし, わが国の新規医療 技術の創出に関する成長率は依然, 欧米各国に比べると 不十分であり, わが国のその一層の進展のためには, 今 後さらにこの流机を加速させていくことが重要であると 考えられる。

本稿では，TRに関するこれまでの世界各国，日本で の取り組みをまとめたうえで，その現状と問題点を整理 する，産業を適切なかたちで医療現場に取り入れるとと もに, 社会への実装へのバリアを超す可能性を高めるた
めのプロセス全体のデザインを組み合わせることで TR の推進, さらにはアカデミアのオープンイノベーション の活性化の一助となることを目指す, 東北大学病院の取 り組みについても言及する。

\section{各国における TR の状況}

各国での TR の位置づけ, 取り組みは異なり, 拠点構 築，人材育成，収支を含めた持続的オペレーション， シーズの育成を含めたノウハウの蓄積など，それぞれ目 指す成果に特徴がある。

\section{1 米国}

米国において，主として TRに関する事業を担当する 機関は NIH の研究所の 1 つである NCATS である. 同研 究所は, 橋渡し研究の加速を図るうえで, 基礎研究の知 見を臨床の現場に橋渡しする過程が十分ではなく，基礎 研究者と医療現場に従事する医師の協力体制が欠如して いた点, 情報工学を多用したデー夕駆動型の医学研究へ の対応の遅れから生物情報学分野の研究者や臨床統計学 分野の研究者を育成する必要性が高まっていた点を解決 する必要がある，との観点から 2011 年に設立された。特 に，後者については，遺伝子解析に伴う疾患の分子レ心゙ ルでの理解，イメージング技術の進歩や情報科学の活 用, さらには臨床の現場においても多くの医療情報が電 子化され研究利用の可能性が急激に拡大したことへの対 応である. 現在, 同研究所の中核的事業に, 2006 年より 開始された臨床・橋渡し研究資金 (Clinical and Translational Science Awards：CTSA) プログラムがある ${ }^{9)}$. CTSA の目的は, 学術機関・病院における統合的な橋渡し研究 の基盤整備であり, 基盤整備, ポスドク支援, 博士研究 者トレーニングの 3 つの手段を活用しながら，(1)ポスド ク支援, 博士研究者トレーニングを中心とした人材育 成, (2)橋渡し研究を円滑に遂行するために必要な, 各拠 点と地域・利害関係者（大学, 産業, 患者団体・市民, 州政府）間の協力，および拠点間の協力構築，(3)基礎研 究・臨床研究者間の協力に加え, 特に薬理学, 情報科学, 統計学分野の専門性を有する研究者の参加も含めた横断 的な研究体制構築，(4)TRに関わる質と効率を高めるプ ロセスの構築のための複数拠点連携と, 生物統計学, 疫 学, ならびに薬事規制（レギュラトリー・サイエンス） などの実践的な助言を行うための相談空口の設置を含む 橋渡し研究に関わる方法論と研究プロセス構築, (5)電子 医療情報, 生体試料を用いた遺伝子解析データなど, 各 種デー夕基盤の整備と統合的研究利用環境の整備, それ 
らを拠点において整備するデータチームの構築を含めた 最先端の情報科学の利用, である. CTSAの成果は論文 や知財というょりも研究環境・教育の取り組みが中心で あると捉えられる。

\section{2 ドイツ}

ドイッで産学間の橋渡しを担う機関としてフラウン ホーファー応用研究促進協会がある ${ }^{1)}$. 設立より 60 年あ まりが経過しており，産学連携を効果的に実施する研究 機関である。フラウンホーファーは, 前競争的領域の研 究を通じて企業のイノベーション創出に寄与することを 目的としており, 基礎研究のシーズをモノやサービスと して市場で利用できるかたちにする橋渡し機能を具現し ている. 具体的な業務としては, (1)企業からの委託研究, (2)研究成果として取得した特許のライセンシング, (3)生 み出した発明や新しいサービスで起業することによる社 会への還元，(4)特に若手の優秀な研究者が産業界で活躍 するためのスキルセットとマインドセットを習得するか たちでの人材育成，(5)企業に対する最先端設備の提供， を柱としている。 人材育成の側面からは, 大学から修士 や博士の学生を採用し, 成果が求めら机る環境下で研究 の主力として 5〜 7年間雇用する。この間に, 研究者は技 術面だけではなく, 顧客とのコミュニケーションを通じ て, 産業界が何を求め, それにはどのような解決方法が あり，なにを用いれば最適に成果として顧客に提供でき るかを実践的に学ぶ。その後, 産業界に転出した研究者 の中には，企業での製品やサービスの開発で生まれた課 題をフラウンホーファーに研究委託するというサイクル が確立している。 ドイッでは，一般的に国立研究所（研 究協会) で研究, 大学は教育, と整理されており, 大学 と国立研究所の物理的近さと教員のクロスアポイントメ ントが特徴である。フラウンホーファーでは, 産業界に 転出した研究者が大学の教員となって研究の現場に戻つ てくるといった事例も多く，人材の循環につながってい る. 医療関係としては, ブレーメンに本拠を置く, 医用 画像演算研究所〔独語名 Institut für Bildgestützte Medizin/英語名 Institute for Medical Image Computing $(\mathrm{MEVIS})]^{2)}$ などいくつかの研究所がある。成果指標は 事業化と収益に力点が置かれているものと考えられる。 今後は，海外企業あるいはドイツ企業の海外現地法人か らの研究委託の増加による財政基盤の多様化, 起業を通 じた基礎研究の社会還元も増加するものと考元られてい る.

\section{3 フランス}

2009 年以降にサルコジ大統領の主導のもとに第 1 群の 投資が行わ机た大規模施策「将来一の投資」により，ラ イフサイエンス強化，デジタル社会への投資を含めた 7 つの軸に沿って科学技術イノベーションにかかる人材育 成, 研究開発・イノベーション活動, プラットフォー ム・拠点設置に加えて研究開発・イノベーション活動, 企業の動機付けに対して投資が行われた。拠点形成に関 しては，イニシアティブ・エクセレンス〔仏語名 Initiative d'excellence (IDEX)。大学・グランゼコールを中心とし たトップレベルの高等教育・研究の拠点を複数設置する プログラムで, 分野横断型研究に取り組むことが重視さ れている], カルノー機関 (企業との共同研究を推進する 国の研究機関に対し認証を与え，その認証に基づき資金 を配分する機関。フラウンホーファー研究所をモデルに 策定され，各機関において次年度に基礎研究に用いるこ とができる予算額が，前年度の企業からの受託研究の規 模に応じて決まる $)^{12)}$, 大学病院研究所 (Institut hospitalo-universitaire (IHU)。医療分野の教育・研究を行う 機関. 大学，大学病院，官民の研究所の連携を前提とし た教育・研究を推進し，基礎研究と臨床医学・産業との 橋渡しを進める $]^{6)}$ などさまざまなプログラムが実施さ れた。 IHU 拠点のある IHU Strasbourg) では，併設され ている IRCAD（仏語名 Institut de Recherche contre les Cancers de l'Appareil Digestif/英語名 Research Institute against Digestive Cancer $)^{7)}$ ともに医用画像誘導手術に 取り組んでいる。IRCADでは，内視鏡外科医のエキス パートを中心とした教育，イノベーションを担う組織で あり，毎年 6,000 名近い外科医が 800 名近くのトップエ キスパートから技術の習得を受けるとともに，施設内の 研究施設に医療機器開発企業が集結し，イノベーション が生まれている。評価指標としては事業化と収益に力点 が置かれているものと考えられる。

\section{わが国における TR の現状と課題}

2007 年度に開始した「橋渡し研究支援推進プログラ ム」では，TRの支援拠点を整備することを目的として (1)橋渡し拠点（計 7 拠点）の機能強化，(2)TR 支援を行 うための人材の確保・登用・育成，(3)TR 支援，(4)橋渡 し拠点の活動・連携の促進，を柱とし，「プログラム期間 内に, 1 機関（拠点）あたり有望な基礎研究の成果が, 2 件ずつ薬事法に基づく治験の段階に移行すること」を目 標に掲げて実施された。2 012 年度より「橋渡し研究加速 ネットワークプログラム」では，画期的な医薬品・医療 


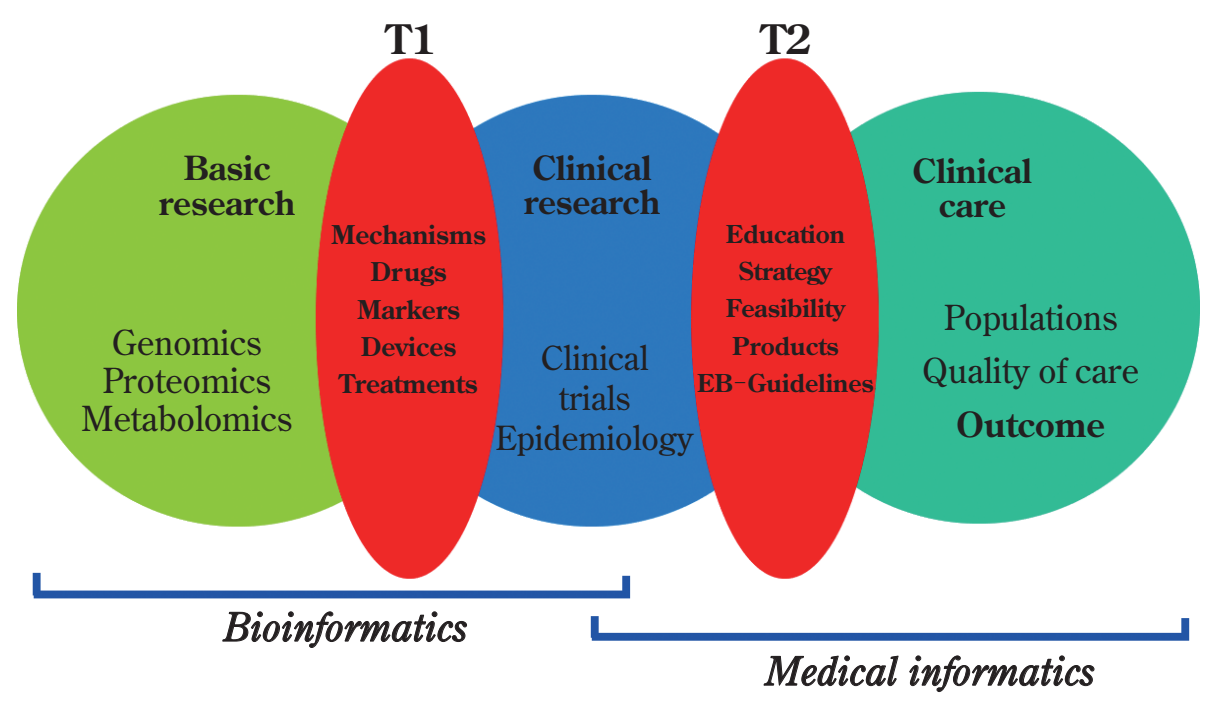

Fig. 1 Translational research model

機器などを効率的・効果的に国民一提供することを目指 し, 大学等発の有望な基礎研究成果の臨床研究・治験へ の橋渡しをさらに加速することを目的として実施され た。具体的には, 全国 9 拠点の「橋渡し研究支援拠点の シーズ育成能力を強化する」こと,「拠点における自己収 入の確保を促進することで恒久的な橋渡し研究支援拠点 を確立させる」ことを目的として, TR を行う基盤整備, 拠点シーズ育成能力の強化など, 恒久的な橋渡し研究の 確立に向けた取り組みが実施された。また, 日本再興戦 略一JAPAN is BACK- (2013 年 6 月 14 日閣議決定), 健 康 ・医療戦略推進法（2014 年成立）といった政策 ・立法 と AMED の設立, 厚生労働省による早期・探索的臨床試 験拠点整備事業 (2011 年度), 臨床研究中核病院整備事 業（2014 年度）といつた事業が施行され，橋渡しを行う ための体制整備も進められた。

TR は，欧米各国における新規医療技術の創出に対し ては科学技術の振興の一翼を担う重要な国家事業として 位置づけられ，産官学の共同体制を構築して，その維持 と育成を図っていることがうかがえる。わが国において も, TRの支援基盤の整備は進み, 臨床応用に向けて成 果を上げてきたといえる，その一方で，(1)産学連携の推 進による基盤整備費によらない運営とシーズ支援料, 知 財などによる収入の多角化を含めた拠点の自立化，(2)事 業終了後も継続可能な実用化の基盤としての支援人材育 成とキャリアパスの確立，(3)シーズの採択・選考プロセ ス，アンメットニーズの観点からの評価やビジネス上の 価値の評価，これらを踏まえた開発計画の策定，また計 画に沿った適正な進渉管理まで含めたシーズ・プロジェ クトマネジメント，(4)拠点間での機能集約化と各拠点の
強みを生かした特色出しといった点が，課題としても考 えられており, 今後の解決に向けた取り組みが進められ るものと考えられる。

これまでの取り組み，課題はトランスレーショナルモ デル13)で考えると理解しやすいものと考えられる。ここ では，基礎研究から臨床研究に移行する $\mathrm{T} 1$ バリアと臨 床研究を社会実装, 改善につなげる $\mathrm{T} 2$ バリアがあり （注：基礎研究から $\mathrm{TR} へ$ T 1 バリア，TRから臨床研究 への T2 バリア, 臨床研究から社会実装研究への T3 バリ ア，社会実装研究から公衆衛生の確立への $\mathrm{T} 4$ バリアと するモデルもある)，それぞれのバリアを超えた橋渡し を経て最終的な社会実装，アウトカムにつなげるステッ プと障壁がわかりやすくモデル化されている（Fig. 1). これらのわが国を含めた橋渡しの取り組みは，まさに， バリアを超えた橋渡しをするための拠点構築を含めた体 制整備，人材育成，シーズの育成を含めたノウハウの蓄 積などの取り組みであるが，一方で，スタンフォード大 学で創立され, 医療機器を中心としてイノベーションに インパクトを与えているバイオデザインプログラム ${ }^{11)}$, あるいは，シリコンバレーなどでデザイン思考を取り入 れて成功している多くの事例は $\mathrm{T} 2$ バリアをいかにして 克服するかに関して示唆を与えるものである。これは, デザイン思考を含めて, 社会実装にいたる一連のプロセ スをデザインする発想を取り入れるものである。ここで は，医療現場などで共感をもって観察を行い，定義づけ されたニーズ (needs statement)を 100〜200 作成するこ とからはじまる。次いで，市場サイズ，競合環境，規制 対応をはじめとした判断基準でこれらを精査し，取り組 むべき課題を明らかにする。続いて，ニーズに基づいた 
コンセプト，プロトタイプの作成を行い，規制対応，事 業化モデルの作成などをステップバイステップで進める ものである，スタンフォードバイオデザインをはじめ, シリコンバレーの企業においても，プロセス全体のデザ インによって大きな成果を上げている. たとえば, InCube $\mathrm{Lab}^{5}$ では, 1995 年設立でこれまで 900 件以上の 特許が成立し， 24 社起業し，15 社が exits（ビジネス用 語で, ベンチャービジネスなどにおいて一定の到達を達 成し, 評価された結果, 株式公開, 事業の売却などによ り創業者などが利益を手にすること）に成功している. しかも，このうちの大半がクラス 3 のデバイスであると ころは注目に值する。こうした考え方を取り入れること で，T2 バリアを超える一助になる可能性があるものと 考えられる。

東北大学病院では, 解決に資する課題を探索するため のプログラム〔東北大学病院ベッドサイドソリューショ ンプログラム アカデミック・サイエンス・ユニット (ASU) ] と方法 (デザイン思考) を組み合わせることで, $\mathrm{T} 2$ バリアを超え, 社会へのインパクトを生み出す可能 性を高めるべく取り組んでおり，それを下記で紹介する。

\section{東北大学における取り組み}

東北大学では, 2003 2007 年度に先進医工学研究機構 を, 次いで, 2007〜2011 年度には未来医工学治療開発セ ンターを設置し, 医工学を中心とした開発研究を行い, 2008 年度にはわが国初の医工学研究科の大学院を設置 した。 また, 2012 年度から, 未来医工学治療開発セン ターと東北大学病院治験センターが発展的に統合するこ とにより, 東北大学病院臨床研究推進センター (Clinical Research, Innovation and Education Center, Tohoku University Hospital：CRIETO）が設置され，他拠点，学外機 関, 学内などと連携しながら臨床研究・試験のみならず, 学内のライフサイエンス研究抒よび東北地区全体の臨床 研究・試験を実施・支援し, 最終的に臨床応用につなげ るミッション，あるいは人材育成を担っている ${ }^{10)}$.

CRIETO の特徵ある取り組みの 1 つに，バイオデザイ ン部門が空口となり, 企業や他分野の研究開発担当者を 共同研究員として病院内に受け入れ, 医療現場（ベッド サイド）を観察し，事業化に資するニーズを医療従事者 とともに探索するプログラム〔東北大学病院ベッドサイ ドソリューションプログラム（アカデミック・サイエン ス・ユニット：ASU)]がある。ここでは，(1)プログラム 参加者に医療現場の濃厚な観察（クリニカルイマージョ ン）機会の提供，(2) “ニーズ”の本質を見極め，企業が
自社のつよみ (Strength)，よわみ（Weakness）あるい は生かしたい機会 (Opportunity) や望ましくない脅威 （Threat）を分析し，医療現場で探索したニーズの中から 自社が取り組むべき課題設定を選択し，ニーズを的確に 満たすコンセプトを創出するブレインストーミング，(3) key opinion leader（KOL）だけでなく，異なるマインド セットや背景をもつ，まったくの異業種，異文化の人材 とのゆるいつながりの構築(ネットワーキング)により， 固定概念やフレームワーク構築にゆらぎを与えてくれる 機会の創出を提供している.

最終的に参加者は医療従事者とともに事業化に資する 課題を設定し，プログラム参加を通じて協働したパート ナーと手を携えて開発研究に着手，あるいは社内既存技 術の pivot（方向転換）に取り組む。その後，プロジェク トマネジメント，規制対応，知財対応部門の支援を受け ながら，出口戦略を見据えつつプロトタイピング，コン セプト証明，非臨床試験，臨床試験ステージへと加速さ せることを目指している.ASUではニーズの探索からコ ンセプト創出，プロトタイピング，事業モデル構築など を中心にニーズに関わる部分を中心に多くの企業と協働 している，ASUでは，デザイン思考なども用いること で，ニーズを探索し，選択する過程で出口に至るまでの 推進，逆に障壁を乗り越えるような課題を選択するプロ セスのデザインをしており，これも前述の $\mathrm{T} 2$ バリアを 超えるための工夫ということができる.

プログラム（6 カ月単位での契約）を開始した 2014 年 3 月〜 2019 年 1 月まで, 医療機器メーカーのみならず, 電子機器，デバイス，材料，創薬，情報通信技術（information and communication technology：ICT）企業など多 種多様な業種から 43 社（うち 6 力月以上の継続参加は 22 社）から 1,300 名以上を共同研究員として受け入れて いる. 医療現場を観察するクリニカルイマージョンは 44 の診療科 (のべ 278 診療科) で 2,617 回実施した。現在, ASU 発の新規事業は 5 件だが，事業化に向けた取り組み はさまざまなかたちで進行している〔特許出願済み 16 件，企業との共同研究締結 9 件，企業研究・開発者の育 成を図る学術指導契約 14 件（いずれも 2018 年 12 月現 在)].

臨床現場への非医療従事者の受け入れが世界的に厳格 化する流れの中で, 本学では 3 年半にわたる法律, 規制, 情報など関連領域の専門家の支援，学内，病院内関係者 の協力を得て体制を整備し，ASU プログラム開始にこぎ つけることができた．現在も多数の医療従事者のみなら ず，さまざまな関係者の支援により本プログラムを実施 している. 


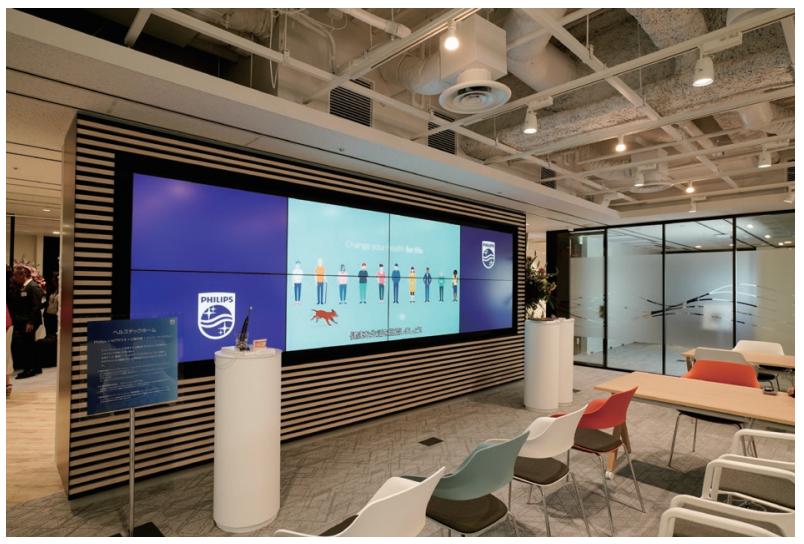

Fig. 2 Philips $\mathrm{Co}^{-}$Creation Center in Sendai
こうした取り組みを背景に, 2018 年 6 月に東北大学は フィリップス・ジャパンと, ICT を活用して疾病予防を 図るソリューションの創出に向け共同研究を進める包括 提携を締結した。また, 2019 年 5 月には東北地域が社会 の変革をリードし, イノベーションの発信に最も適した エリアであると考え, フィリップス日本初のイノベー ション研究開発拠点として, Philips $\mathrm{Co}^{-}$-Creation Center （Fig.2）を宮城県仙台市に設立した。ここでは，デジ夕 ル ICT 変革による健康・予防・医療への新たな価值創造 に向け，大学，医療機関，企業，自治体をはじめとする さまざまな組織との共創（co-creation）の場となること が期待されており，この取り組みをさらに推進するた め, 2018 年 6 月に Philips $\mathrm{Co}^{-}$Creation Satellite (Fig. 3) が東北大学病院内にオープンした。プレス会見の中で大 野英男東北大学総長は, 「とりわけ東北地方では, 人口減 少, 超高齢化, 医療へのアクセシビリティの低下など深 刻な課題を抱えている. 今回の提携を通じて, これらの 諸課題に対して適切な課題設定を行い, 最新のテクノロ ジーを上手に組み合わせることで克服し, 地域に貢献す るとともに，グローバルへの貢献につなげていきたい」 と, グローバル協㗢を視野に入れたソリューションを新 たに構築する点も含めた提携の意義を強調した。 ロイヤ ルフィリップスのファン・ホーテン最高経営責任者か らは,「健康をより増進し, 持続可能なものにしていくに はイノベーションが必要である。しかし，フィリップス 単独ではできない，東北大学は医療現場を深く洞察する システムと課題の本質を捉え事業化につなげる方法に関 して深い知識と知見をもっている」と述べ, 共同で取り 組む意義を説明した。また，フィリップス・ジャパンの 堤 浩幸社長からは, 超高齢化に伴う健康, 医療上の課題 を挙げ,「東北の課題は日本の課題であり, 近い将来の世

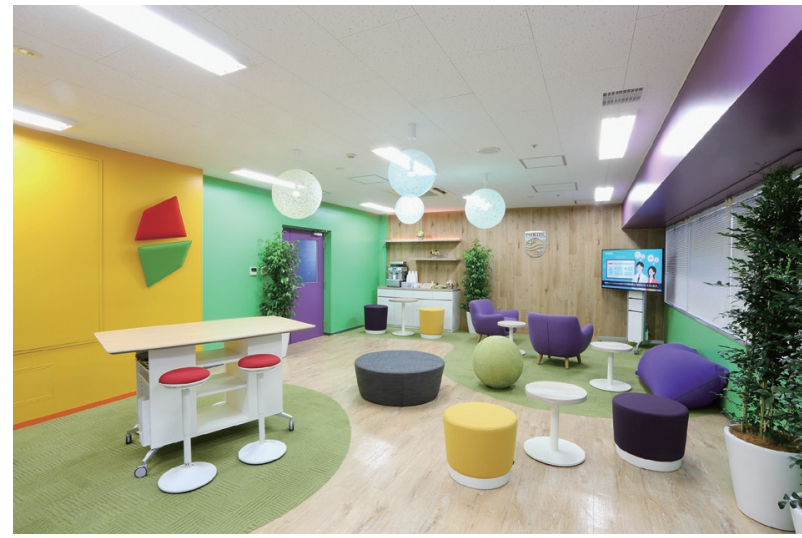

Fig. 3 Philips Co-Creation Satellite in Tohoku University Hospital

界の課題である」と指摘し,「この東北から，仙台から， 日本から, 将来を左右するイノベーションを生み出す, 社会の変革をリードできる地域にする」と, 意気込みが 語られた。

フィリップス・ジャパンの開発研究者がASUで歯学部 を中心とした医療・健康の現場観察を開始し，ニーズを 探索し, 引き続いて, フィリップスが有するテクノロ ジー，同社がグローバルで有するリソース，日本のイン サイトがグローバルにどのように展開できるかに関する 考察など，さまざまな視点を念頭に解決すべきニーズを 選択を行った。そのうえで，これらを解決するビジネス モデルの考案，プロトタイピングを繰り返すという一連 のソリューション開発プロセスを質についてスピードを 両立させながら取り組んでいる。

また，CRIETO 内（Fig. 4)，あるいは Philips Co-Creation Center 内には仮想現実 (virtual reality：VR）や拡張 現実（augumented reality：AR）を使用した空間を構築 し, 今後発展する新しいテクノロジー (emerging technology)に触れることのできる機会を設けることで従来の発 想にとらわれないコンセプトが出やすくするとともに, これからのへルステックを担う人材のすそ野を広げる場 としても活用する予定である.

ニーズ探索の場として，医療現場としての大学病院は 重要であることはいうまでもないが，その一方で，大学 病院は医療・ヘルスケア分野の一部を担っているにすぎ ず，現状の俯瞰的な理解と潜在的な課題を可視化する必 要がある。そのため, 疾病を発症してから, 地域診療所 や病院（疾患によっては地域中核病院や大学病院）にお いて治療後，外来通院する中で，事業化に資するニーズ を探索するためには，医療従事者の立場からみた治療》 ロー，患者の立場からみた patient journey，それぞれの 

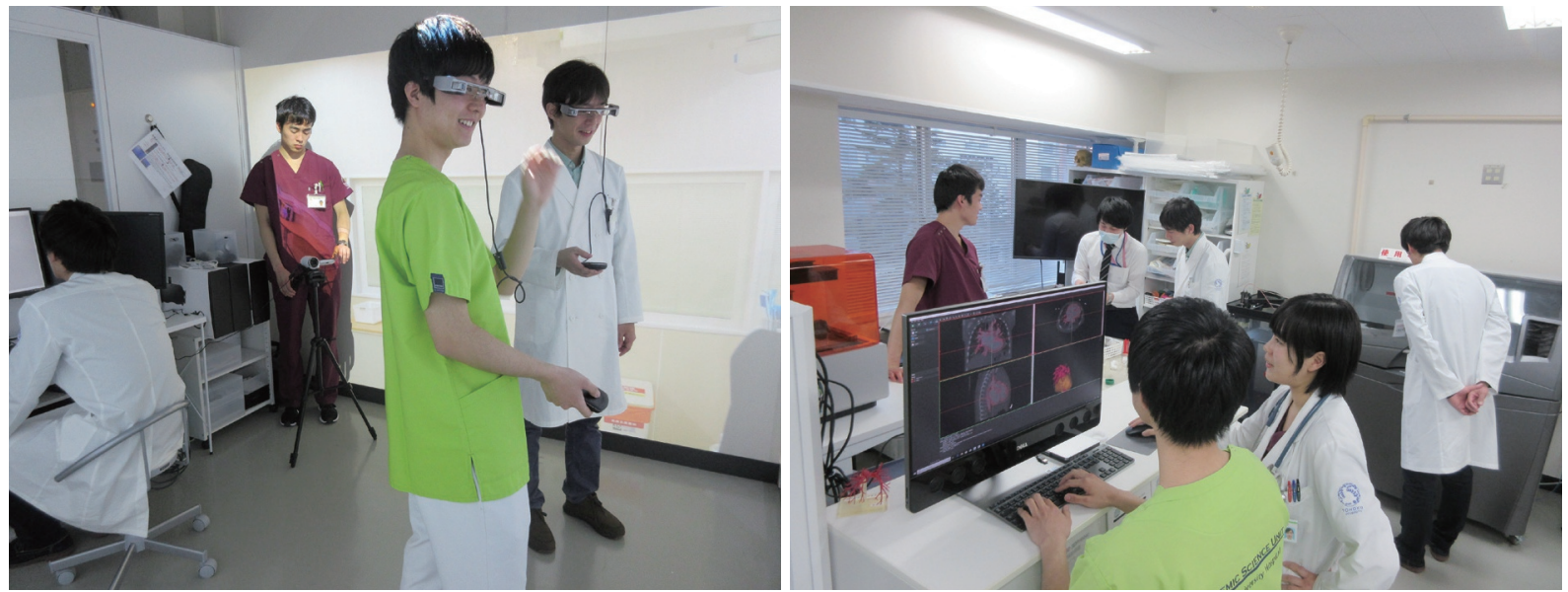

Fig. 4 Digital Health Test Lab in Clinical Research, Innovation and Education Center, Tohoku University Hospital (CRIETO)

場面で多岐にわたるステークホルダーの立場からみた業 務フローを時間・地域・組織横断的に比較することがき わめて重要であり，これらをカバーする体制の整備を進 めているところである，今後の方向性としては，産業界 と連携してイノベーションを持続的に興すためのハブと しての機能強化と医療プロフェッショナルのリエゾン人 材の育成である。

\section{まとめ}

TRに関するこれまでの世界各国，日本での取り組み をまとめたうえで，その現状と問題点を整理した。また， 産業を適切なかたちで医療現場に取り入れるとともに, 社会への実装へのバリアを超す可能性を高めるためのプ ロセス全体のデザインを組み合わせ，イノベーションの ハブとしてのアカデミア医療機関を目指す東北大学病院 の取り組みを紹介した。

\section{謝 辞}

本稿は脳神経外科アドミニストレーター金田恵美子氏，菅 井恭子氏, 東北大学病院臨床研究推進センターバイオデザイ ン部門改正将夫氏, 庄司貞夫氏，日下房子氏，寺島なお子氏， 東北大学医学部兒崎琢磨氏に情報収集，分析で支援をいただ いたので謝意を表す。

著者のうち，佐藤千穂，八木橋真央，高橋千明は，自己申 告による COI 報告書を日本脳神経外科コングレス事務局に提 出しています。その他の著者全員は, 日本脳神経外科学会へ の COI 自己申告の登録を完了しています，いずれも，本論文 に関して開示すべきCOI はありません。

\section{文 献}

1) Fraunhofer Home Page. https://www.fraunhofer.de/en.htm (2019 年 9 月閲覧)

2) Fraunhofer MEVIS Home Page. https://www.mevis.fraun hofer.de/(2019 年 9 月閲覧)

3）橋渡し研究戦略的推進プログラム中間評価委員会：橋渡 し研究支援総合戦略. Aug, 6, 2019. https://www.life science.mext.go.jp/files/pdf/n2197_1-2.pdf (2019 年 9 月閲 覧)

4) IHU Strasbourg Institut de Chirurgie guidée par l'Image Home Page https://www.ihu-strasbourg.eu/en/(2019 年 9 月閲覧)

5) Incube Labs Home Page. https://www.incubelabs.com (2019 年 9 月閲覧)

6) Instituts Hospitalo-Universitaires Home Page. https:// www.ihu-france.org/fr/ (2019 年 9 月閲覧)

7) IRCAD Home Page. https://www.ircad.fr/(2019 年 9 月閲 覽)

8) National Center for Advancing Translational Sciences Home Page. https://ncats.nih.gov/translation（2019 年 9 月閲覧）

9) National Center for Advancing Translational Sciences : Clinical and Translational Science Awards (CTSA) Program. https://ncats.nih.gov/ctsa（2019 年 9 月閲覽）

10）下川宏明：“東北発” 先端医療の創成を目指して一東北大 学病院臨床研究推進センターの取り組み。日薬理誌 146: 47-53, 2015 .

11) Stanford Biodesign Home Page. http://biodesign.stanford. $\mathrm{edu} /(2019$ 年 9 月閲覽)

12) The Carnot Network Home Page. https://www.insti tuts-carnot.eu/en/carnot-network-presentation（2019 年 9 月閲覧）

13) Vaughan C : School of Medicine Retreat Tackles Translational Research. University of California San Francisco. Jan. 25, 2007. https://www.ucsf.edu/news/2007/01/7704/ school-medicine-retreat-tackles-translational-research2 (2019 年 9 月閲覧) 
要旨

橋渡し研究

一最近の変化と現状の問題点一

中川 敦寛 佐藤 千穂 八木橋真央 高橋 千明 冨永 悌二

近年, 優れた研究成果を社会に実装するために橋渡し研究（translational research：TR）が世界各 国でそれぞれの課題に即したかたちで進められてきた. 一般的には TR モデルでは, 基礎研究から臨 床研究に移行する $\mathrm{T} 1$ バリアと臨床研究を社会実装, 改善につなげる $\mathrm{T} 2$ バリアがあり, 拠点構築, 人 材育成, 収支を含めた持続的運営, シーズ育成を含めたノウハウ蓄積の観点からそれぞれの取り組み が特徵づけられる. これまでの世界各国, 日本での取り組みをまとめ, その現状と問題点を整理する. 産業を適切なかたちで医療現場に取り入れ, バリアを超す可能性を高めるプロセス全体のデザインを 含め東北大学病院の取り組みを紹介する.

脳外誌 $29: 760-767,2020$ 